\title{
Routine Vaginal Cuff Smear Testing in Post- Hysterectomy Patients With Benign Uterine Conditions: When Is It Indicated?
}

\author{
Andrea Videlefsky, MD, Norman Grossl, MD, Maxine Denniston, MSPH, \\ Rajneesh Sebgal, MD, J. Michael Lane, MD, MPH, and \\ Gerald Goodenough, MD, MSPH
}

Background: By the age of 60 years, an estimated $33 \%$ of women will have undergone a hysterectomy. Approximately $85 \%$ of these hysterectomies are performed for benign disease. The object of this study was to evaluate cytologic findings from vaginal cuff smears in patients who have undergone hysterectomy for benign uterine conditions.

Methods: We conducted a community-based retrospective study and follow-up of women with vaginal cuff cytologic smears who had had a hysterectomy for benign uterine conditions. A total of 220 women were randomly selected who had one or more vaginal cuff smears. The main outcomes measures were invasive carcinoma, dysplastic lesions, and infections detected by vaginal cuff smear testing. The setting was a large inner-city hospital.

Results: Ninety-seven percent of 220 women who underwent hysterectomy for benign uterine conditions and who were observed for an average of 89 months had no cytologic abnormalities on vaginal cuff smears. Cytologic evaluation found no invasive carcinomas. Dysplastic lesions were detected in 7 patients $(3 \%)$. Seventy percent of patients $(n=154)$ had one or more infections; these infections included bacterial vaginosis (106), trichomoniasis (95), candidiasis (40), koilocytosis suggestive of human papilloma virus (HPV) infection (3), and cytopathic effect of herpes (4). The prevalence of koilocytosis was much higher in the patients with dysplasia $(P=.0003)$.

Conclusions: Most routine vaginal cuff cytology screening tests need not be performed in women who have had a hysterectomy for benign uterine conditions. (J Am Board Fam Pract 2000;13:233-8.)

Many women in the United States undergo hysterectomy for benign gynecologic conditions. An estimated more than $33 \%$ of women in the United States will undergo hysterectomy by the age of 60 years. Approximately $85 \%$ of these operations are done for benign disease. ${ }^{1}$ The Papanicolaou smear

Submitted, revised, 22 February 2000.

From the Department of Family and Preventive Medicine (AV, JML) and the Department of Pathology and Laboratory Medicine (NG, RS), Emory University School of Medicine, and the Department of Anatomic Pathology and $\mathrm{Cy}$ tology (NG), Grady Memorial Hospital, Atlanta; the Senior Health Center, St. Marks Hospital (GG), Salt Lake City; and the American Cancer Society (MD), Atlanta. Address reprint requests to Norman Grossl, $M D$, Department of Pathology, 80 Butler St, Atlanta, GA 30335.

This work is supported by the Departments of Family Medicine and Pathology and Laboratory Medicine, Emory University School of Medicine, and by the Department of Anatomic Pathology and Cytology, Grady Memorial Hospital, Atlanta.

'This article was presented at the AAFP Scientific Assembly in September 1997. was originally designed to detect cervical carcinomas. ${ }^{2}$ Its primary current use is to detect premalignant and malignant cervical lesions. The incidence of vaginal cancers as well as dysplasia in women who have had a hysterectomy for benign conditions is low. ${ }^{3}$ The incidence of primary vaginal carcinoma is far less than that of cervical and endometrial carcinomas. ${ }^{4,5}$ The American Cancer Society estimated 2300 new cases of primary vaginal carcinomas in the US general population for 1999. In contrast, there were an estimated 37,400 new cases of endometrial cancers and 12,800 projected cases of cervical cancers for the same period. ${ }^{6}$ There was previously no consensus regarding cytologic testing of vaginal cuff smears in the follow-up of these patients for surveillance of vaginal malignancies. ${ }^{7,8}$ A recent study of vaginal smear findings in more than 5,000 women who had undergone hysterectomy concluded that periodic routine screening by 
means of vaginal Papanicolaou smears is probably not necessary for women whose indication for hysterectomy was benign. ${ }^{9}$ This study addressed current negative findings on smears but did not observe the outcome of these patients with time.

Our study differs from previous studies in that we included patients with high-grade prehysterectomy precursor lesions in the study group, and we observed patients with abnormal posthysterectomy findings to assess a long-term outcome. Although vaginal cuff smears appear not to be cost-effective as a screening tool for detection of vaginal lesions, ${ }^{10}$ many physicians perform routine vaginal cuff smears for cytologic follow-up. The current guidelines from professional organizations do not provide a clear consensus regarding the use of vaginal cuff cytologic testing in patients who have had a hysterectomy for benign uterine conditions. ${ }^{11-18}$ To investigate the usefulness of vaginal cuff cytologic testing in women who have had a hysterectomy for benign conditions, we analyzed results of vaginal cuff smears in a cohort of 220 women cared for at Grady Memorial Hospital. This hospital serves a predominantly inner-city, lower socioeconomic community in Atlanta.

\section{Methods}

The Computer Information System Section in the Department of Pathology and Laboratory Medicine at Grady Memorial Hospital conducted a computer-generated search for patients who had total hysterectomies for benign uterine conditions and who had follow-up vaginal cuff smear testing. We selected all patients who had one or more vaginal cuff smears performed between April 1987 and July 1996. A total of 2066 patients met these search criteria. A random selection from this group yielded a sample population of 220 women. We obtained the patients' cytology, biopsy, and hysterectomy results by computer search, and we evaluated further management information for all patients with abnormalities found on vaginal cuff smears by reviewing their charts. We used Epi-Info 5.01 and SAS 6.12 to analyze the data. ${ }^{19,20}$

\section{Cytology Definitions}

Prehysterectomy dysplasia included dysplastic lesions detected by Papanicolaou smears, cervical biopsies, cervical cone specimens, and the cervical uterus at hysterectomy. Posthysterectomy dysplasia includes dysplastic lesions detected by vaginal cuff smears and vaginal biopsies.

\section{Results}

The mean age of the patients at hysterectomy was 44.4 years $(\mathrm{SE}=0.73$ ), with a range of 23 to 79 years. The 220 patients yielded 1,211 follow-up vaginal cuff smears. The number of vaginal cuff smears performed in individual cases ranged from 1 to 21 , with a mean of $5.5(\mathrm{SE}=0.23)$. The mean time between vaginal cuff smears, when at least two were performed, was 19.5 months $(\mathrm{SE}=0.82$ ), with a range of 4 to 78 months. In 14 patients only one vaginal cuff smear was performed. In the entire group of 220 women, the mean time between hysterectomy and the first vaginal cuff smear was 13.2 months $(\mathrm{SE}=1.19)$, with a range from the same month of hysterectomy to 155 months posthysterectomy. The average period of follow-up (from the time of hysterectomy to the most recent vaginal cuff smear) for the 220 patients was 89.0 months $(\mathrm{SE}=2.81$ ), with a range of 3 to 175 months.

All patients underwent a total hysterectomy for benign uterine conditions. The indications for hysterectomy were noted in the chart or found on pathologic examination. Uterine leiomyomata accounted for hysterectomy in most cases. Adenomyosis was the next most common histologic finding.

Before hysterectomy, $164(74.5 \%, \mathrm{SE}=2.9)$ of the 220 patients had no cytologic abnormalities. Low-grade squamous intraepithelial lesions (including human papillomavirus [HPV]-induced changes and mild dysplasia) were found in 12 patients $(5.5 \%, \mathrm{SE}=1.5)$. High-grade squamous intraepithelial lesions (including moderate and severe dysplasia) were detected in $44(20.0 \%, \mathrm{SE}=$ 2.7) patients. Although those with high-grade lesions had severe precursor lesions, they were included in our analysis. No patient with a preexisting invasive carcinoma or carcinoma-in situ was included in the study group. Cytologic evaluation found no invasive carcinomas after hysterectomy.

There were 213 patients $(97 \%, \mathrm{SE}=1.2)$ who had normal findings on vaginal cuff smears. We detected abnormal cytologic findings on the vaginal cuff specimens in 7 patients $(3 \%, \mathrm{SE}=1.2)$. The overall probability of an abnormal vaginal cuff test finding is 0.006 .

In the 7 patients with abnormal posthysterectomy cytologic findings, the average number of cuff 
Table 1. Natural Progression of Disease in 4 Women with Hysterectomy for Benign Conditions Who Had Positive Findings on Vaginal Cuff Smear (VCS) and No Biopsies or Interventional Procedures.

\begin{tabular}{clcccc}
\hline Patient & $\begin{array}{c}\text { Indication for } \\
\text { Hysterectomy }\end{array}$ & $\begin{array}{c}\text { Interval VCSs } \\
\text { Before Abnormal } \\
\text { Findings }\end{array}$ & $\begin{array}{c}\text { VCS } \\
\text { Abnormalities }\end{array}$ & $\begin{array}{c}\text { Months After } \\
\text { Hysterectomy } \\
\text { No. }\end{array}$ & Follow-Up \\
\hline 1 & Adenomyosis & NA & Moderate dysplasia \\
2 & Leiomyomas & 7, negative & $\begin{array}{c}\text { Atypical squamous cells of } \\
\text { undetermined significance }\end{array}$ & 188 & Lost to follow-up \\
3 & $\begin{array}{c}\text { Leiomyomas } \\
\text { Leiomyomas, } \\
\text { adenomyosis }\end{array}$ & Na negative & $\begin{array}{l}\text { Mild dysplasia } \\
\text { Mild dysplasia, human } \\
\text { papillomavirus infection }\end{array}$ & 132 & 1 negative VCS at 2 mo \\
& NA & 11 & 1 negative VCS at 1 mo \\
\hline
\end{tabular}

smears performed was $8.0(\mathrm{SE}=1.2)$, which is different $(t=1.94, d f=218, P=.0535)$ from the group with normal posthysterectomy cytologic findings (average $=5.4, \mathrm{SE}=0.24$ ). Clinical information on the 7 patients found to have posthysterectomy cytologic abnormalities is displayed in Tables 1 and 2. These 7 patients were analyzed separately according to the follow-up treatment and interventions they received. Four of these patients (Table 1) received no biopsies or other interventions (allowing for natural progression of disease), and the other 3 underwent therapeutic biopsies, laser treatments, or excision of the abnormal tissue (Table 2). On long-term follow-up, vaginal cuff specimens for these 7 patients were negative for dysplasia in all patients except 1 , who had atypical squamous cells of undetermined significance and for whom no follow-up information was available.

Table 3 outlines the correlation of cytologic findings before and after hysterectomy. There were 164 patients $(74.6 \%, \mathrm{SE}=2.9)$ with completely normal prehysterectomy cytologic results, 5 (3\%, $\mathrm{SE}=1.3$ ) of whom subsequently developed posthysterectomy dysplasia; and there were $56(25.4 \%$, $\mathrm{SE}=2.9$ ) patients with abnormal prehysterectomy results, of whom only $2(3.6 \%, \mathrm{SE}=2.5)$ had abnormal findings in the posthysterectomy period (Table 3). Patients with abnormal cytologic findings before hysterectomy were at no greater risk for abnormal posthysterectomy cytologic findings $(\mathrm{RR}=1.13,95 \% \mathrm{CI}=0.34$ to 3.72$)$ than those

Table 2. Clinical and Cytopathologic Information for 3 Posthysterectomy Patients with Abnormal Vaginal Cuff Smear (VCS) Findings Who Received Further Therapeutic Interventions.

\begin{tabular}{|c|c|c|c|c|c|c|}
\hline Patient & $\begin{array}{c}\text { Prehysterectomy } \\
\text { Findings }\end{array}$ & $\begin{array}{l}\text { Indication for } \\
\text { Hysterectomy }\end{array}$ & $\begin{array}{c}\text { VCS } \\
\text { Abnormalities }\end{array}$ & $\begin{array}{c}\text { Months } \\
\text { Posthysterectomy }\end{array}$ & $\begin{array}{l}\text { Biopsy } \\
\text { Results }\end{array}$ & $\begin{array}{l}\text { Long-term VCS } \\
\text { Follow-up Testing }\end{array}$ \\
\hline 1 & Negative & $\begin{array}{l}\text { Endometrial } \\
\text { hyperplasia }\end{array}$ & $\begin{array}{l}\text { Moderate, with } \\
\text { HPV infection }\end{array}$ & 6 & $\begin{array}{l}3 \text { negative, chronic } \\
\text { inflammation }\end{array}$ & 3 negative, $103 \mathrm{mo}$ \\
\hline 2 & Negative & Leiomyomas & $\begin{array}{l}\text { Mild atypia, } \\
\text { moderate } \\
\text { dysplasia }\end{array}$ & 26 & $\begin{array}{l}\text { Severe vaginal } \\
\text { dysplasia }\end{array}$ & 7 negative, $40 \mathrm{mo}$ \\
\hline \multirow[t]{4}{*}{3} & \multirow{4}{*}{$\begin{array}{c}\text { Mild dysplasia on } \\
\text { cervical biopsy. } \\
\text { No uterine } \\
\text { abnormalities }\end{array}$} & \multirow[t]{4}{*}{$\begin{array}{l}\text { Mild dysplasia } \\
\text { of the cervix }\end{array}$} & \multirow{4}{*}{$\begin{array}{l}\text { Mild dysplasia, } \\
\text { atypical squamous } \\
\text { cells of } \\
\text { undetermined } \\
\text { significance, HPV } \\
\text { infection }\end{array}$} & 82 & \multirow[t]{4}{*}{$\begin{array}{l}\text { Mild vaginal } \\
\text { dysplasia }\end{array}$} & $\begin{array}{l}2 \text { negative, } 22 \text { mo } \\
\text { HPV infection with } \\
\text { mild atypia }\end{array}$ \\
\hline & & & & & & $\begin{array}{l}\text { 2nd biopsy: mild } \\
\text { dysplasia and } \\
\text { HPV infection } \\
\text { with koilocytosis. }\end{array}$ \\
\hline & & & & & & Normal, $3 \mathrm{mo}$ \\
\hline & & & & & & $\begin{array}{l}13 \text { mo later: atypical } \\
\text { squamous cells of } \\
\text { undetermined } \\
\text { importance }\end{array}$ \\
\hline
\end{tabular}

HPV = human papillomavirus. 
Table 3. Cytologic Findings Before and After Hysterectomy in 220 Patients Who Had Hysterectomy for Benign Conditions.

\begin{tabular}{lllr}
\hline Prehysteerectomy Findings & No. (\%) & \multicolumn{1}{c}{ Posthysterectomy Findings } & No. (\%) \\
\hline Normal cytologic findings & $164(74.6)$ & Normal cytologic findings & $159(96.0)$ \\
& & Mild atypical squamous cells of undetermined significance & $2(1.2)$ \\
& & Low-grade lesions + HPV infection & $1(0.6)$ \\
& & Moderate-severe dysplasia & $1(0.6)$ \\
Low-grade lesions & High-grade lesions + HPV infection & $1(0.6)$ \\
High-grade lesions & $12(5.4)$ & Normal & $12(100.0)$ \\
& $44(20.0)$ & Normal & $42(95.5)$ \\
& & Severe dysplasia + HPV infection & $2(4.5)$ \\
\hline
\end{tabular}

HPV - human papillomavirus.

with normal prehysterectomy cytologic findings $\left(\chi^{2}=0.04, P=.847\right)$.

Of the 220 patients in this study, 154 (70.0\%, $\mathrm{SE}=3.1$ ) had one or more infections diagnosed on their posthysterectomy vaginal cuff smear reports. Infections reported include bacterial vaginosis (106), trichomoniasis (95), candidiasis (40), koilocytosis (HPV infection) (3), and cytopathic effect of herpes (4). Some patients were noted to have more than 1 infection, giving a total number of 248 infections. Thirty-eight (15.3\%) of these infections were due to bacterial vaginosis only and were not considered clinically important. Of the remaining 210 infections, 201 were from the 213 patients who had normal cytologic findings, and 9 were from the 7 patients who had posthysterectomy dysplasia. $\mathrm{Pa}$ tients with infections were at no greater risk of having posthysterectomy dysplasia $(R R=1.37$, $95 \% \mathrm{CI}=0.84-2.23)$ than those with no infections (Fisher exact test, $P=.451$ ). The risk of posthysterectomy dysplasia was much greater $(R R=60.9$, $95 \% \mathrm{CI}=6.2-594.6$ ) for patients with koilocytosis (Fisher exact test $P=.003$ ). Table 4 summarizes the data on posthysterectomy infections.

\section{Discussion}

Seven patients $(3 \%)$ had posthysterectomy cytologic abnormalities detected on vaginal cuff smears. None of these patients went on to develop vaginal cancers, indicating a low rate of serious vaginal disease detected by vaginal cuff smear testing. Prehysterectomy cervical cytologic abnormalities did not necessarily predict posthysterectomy cytologic abnormalities in this study. There was no association between the presence or severity of preexisting cervical dysplasia and posthysterectomy abnormalities (Table 3). Whereas the proportion of women with prehysterectomy abnormalities who went on to develop posthysterectomy dysplasia was increased slightly, this finding was not statistically significant. Contrary to findings in other studies which have shown that precursor and malignant squamous lesions of the cervix are important predisposing factors for precursor and malignant vaginal lesions, ${ }^{21-24}$ our findings do not support this association. The importance of HPV in the development of vaginal neoplasia is controversial. ${ }^{24}$ In this study, patients with HPV infection were noted

Table 4. Infections Detected After Hysterectomy by Cervical Cytologic Testing in 212 Women, by Cytologic Classification and Type of Infection.

\begin{tabular}{lccc}
\hline Infection & $\begin{array}{c}\text { Patients with } \\
\text { Normal Findings } \\
(\mathrm{n}=201)\end{array}$ & $\begin{array}{c}\text { Patients with } \\
\text { Dysplasia } \\
(\mathrm{n}=11)\end{array}$ & $\begin{array}{c}\chi^{2} \text { or Fisher } \\
\text { Exact Test } \\
P \text { Value }\end{array}$ \\
\hline Candidiasis & 39 & 1 & .4 \\
Herpes & 4 & 0 & .8 \\
Bacterial vaginosis & 67 & 1 & .18 \\
Trichomoniasis & 90 & 5 & .6 \\
Koilocytosis & 1 & 2 & .003 \\
\hline
\end{tabular}


to have dysplastic lesions more frequently. Women at high risk for HPV infection might require ongoing surveillance, regardless of their indication for cytologic evaluation of vaginal cuff smears. Further studies are required to determine the most costeffective method of maintaining surveillance for HPV infection and to assess whether these patients require cytologic follow-up.

Dysplastic cervical and vaginal lesions frequently regress spontaneously. In our study, 4 patients with posthysterectomy abnormalities had no biopsies performed, and all subsequent vaginal cuff specimens were negative for dysplasia on long-term follow-up (except for 1 patient with atypical squamous cells of undetermined significance for whom no follow-up information was available). In the 3 patients who underwent some form of intervention, all follow-up vaginal cuff smears were negative for dysplasia except for 1 patient who had atypical squamous cells of undetermined significance. In the latter group, the natural progression of disease is not known because of intervention. The interventions performed might have proved to be curative for lesions that might otherwise have progressed to serious disease.

Ninety-seven percent $(97 \%)$ of women who underwent hysterectomies for benign conditions and were observed for an average period of 89 months had no cytologic abnormalities on vaginal cuff smears. This study group had an average of 6 vaginal cuff smears performed at 19-month intervals. Many infections, including HPV and herpes, which are important precursor lesions for the development of dysplasia, were detected by vaginal cuff smear testing.

Our study showed that patients in the group with posthysterectomy abnormalities had somewhat closer follow-up with a greater number of vaginal cuff smears performed. Despite closer follow-up and increased expenditure on vaginal cuff smears, the outcome for these patients did not differ from the group as a whole, as no patient in the study went on to develop malignancy. Our study is limited because few patients had abnormalities found after hysterectomy, and the patients were observed for a limited time. Surgical or ablative interventions could have altered the outcome for some patients. In this era of cost containment and managed care, all efforts should be made to decrease the practice of unnecessary evaluations. Currently there is no scientific evidence to support the practice of routine vaginal cuff smear testing after hysterectomy for benign disease.

\section{Recommendations}

Each patient who has had a hysterectomy for a benign uterine condition should be counseled individually regarding the risks and benefits of decreasing or abandoning the practice of follow-up vaginal cuff smear tests. Guidelines should be formulated based on pertinent history and clinical data in the following areas:

1. Assess whether the hysterectomy was indeed done for a benign condition.

2. Assess whether there were any underlying coexisting genital tract malignancies or dysplasia at the time of or preceding the hysterectomy, including ovarian, vaginal, or perineal abnormalities.

3. Assess the probability of vaginal infections based on the history of sexual practices and previous sexually transmitted infections.

4. Consider the practice setting. Patients more likely to develop vaginal cancers include those in lower socioeconomic groups, patients with HPV infection, and patients who are immunocompromised.

\section{Conclusion}

This study provides support for previous studies that concluded that posthysterectomy vaginal cuff smear testing is no longer necessary in patients who had a hysterectomy for benign conditions.

Once all appropriate recommendations have been considered, patients can be counseled that there are currently no known scientific benefits from routine vaginal cuff smear screening, and there can be possible risks associated with performing unnecessary procedures. Because the incidence of vaginal cancer is extremely low, prospective studies of screening for vaginal cancer would require a great many patients and would be prohibitively expensive. It might be worthwhile, therefore, to investigate retrospective case-control trial methods to determine whether specific subgroups of patients might potentially benefit from screening.

The authors wish to thank Audrey Gohr of the Computer Information System Section, Department of Pathology and Laboratory Medicine, Grady Memorial Hospital, Atlanta, for the computer search performed in this study. 


\section{References}

1. Pokras R, Hufnagel VG. Hysterectomy in the United States, 1965-84. Am J Public Health 1988; 78:852-3.

2. Papanicoloau GN, Traut HF. Diagnosis of uterine cancer by the vaginal smear. New York: Commonwealth Fund, 1943.

3. Piscitelli JT, Bastian LA, Wilkes A, Simel DL. Cytologic screening after hysterectomy for benign disease. Am J Obstet Gynecol 1995;173:424-32.

4. Johnston GA Jr, Klotz J, Boutselis JG. Primary invasive carcinoma of the vagina. Surg Gynecol Obstet 1983;156:34-40.

5. Cramer DN, Cutler SJ. Incidence and histopathology of malignancies of the female genital organs in the United States. Am J Obstet Gynecol 1974;118: 443-60.

6. Pap test. Atlanta: American Cancer Society, 1991.

7. Fawdry RD. Carcinoma-in-situ of the cervix: is posthysterectomy cytology worthwhile? $\mathrm{Br} \mathrm{J}$ Obstet Gynaecol 1984;91:67-72.

8. Bell J, Sevin BU, Averette H, Nadji M. Vaginal cancer after hysterectomy for benign disease: value of cytologic screening. Obstet Gynecol 1984;64: 699-702.

9. Pearce KF, Haefner HK, Sarwar SF, Nolan TE. Cytopathological findings on vaginal Papanicolaou smears after hysterectomy for benign gynecologic disease. N Engl J Med 1996;335:1559-62.

10. Fetters MD, Fischer G, Reed BD. Effectiveness of vaginal Papanicolaou smear screening after total hysterectomy for benign disease. JAMA 1996;275: 940-7.

11. Age charts for periodic health examinations. Kansas City, Mo: American Academy of Family Physicians, 1993.

12. AMA consensus statement. Policies of House of Delegates I-96. Statement number H-525.995: Papanicolaou tests in healthy women. Chicago: American Medical Association, 1993.

13. Eddy DM. Screening for cervical cancer. In: Eddy DM, editor. Common screening tests. Philadelphia: American College of Physicians, 1991:255-85.
14. Pap test. Atlanta: American Cancer Society, 1991.

15. What you need to know about cancer of the cervix. Bethesda, Md: National Cancer Institute, 1990.

16. Recommendations on frequency of Pap test screening: ACOG committee opinion. Washington, DC: American College of Obstetricians and Gynecologists, 1995:152.

17. National Health Service Cervical Screening Programme. Health service guidelines-NHS management executive. Sheffield, England: National Cervical Screening Programme, 1993.

18. Cervical cancer screening programs: summary of the 1982 Canadian task force report. Can Med Assoc J 1982;127:581-9.

19. Dean AG, Dean JA, Coulombier D, et al. EpiInfo, version 6: a word-processing database and statistics program for public health on IBM compatible microcomputers. Atlanta, Ga: Centers for Disease Control and Prevention, 1995.

20. SAS/STAT users guide, version 6. 4th ed. Volume 1 . Cary, NC: SAS Institute, 1989.

21. Gallup DG, Talledo OE, Shah KJ, Hayes C. Invasive squamous cell carcinoma of the vagina: A 14year study. Obstet Gynecol 1987;69:782-5.

22. Gallup DG, Morley GW. Carcinoma in situ of the vagina: a study and review. Obstet Gynecol 1975;46: $334-40$.

23. Schiffer MA, Mackles AM, Greene HJ. Carcinoma in situ of the vagina after hysterectomy. Surg Gynecol Obstet 1972;134:653-4.

24. Wiener JJ, Sweetnam PM, Jones JM. Long term follow-up of women after hysterectomy with a history of pre-invasive cancer of the cervix. $\mathrm{Br} \mathrm{J}$ Obstet Gynaecol 1992;99:907-10.

25. Schneider A, de Villiers EM, Schneider V. Multifocal squamous neoplasia of the female genital tract: significance of human papilloma virus infection of the vagina after hysterectomy. Obstet Gynecol 1987; 70:294-8.

26. US Preventive Services Task Force. Guide to clinical preventive services. 2nd ed. Baltimore, Md: Williams \& Wilkins; 1996:xxxix-lv. 